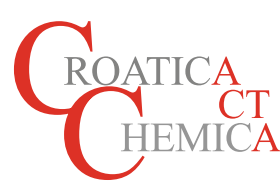

\title{
Students Remember Siniša Maričić (1926-2017): Upright to the End
}

\author{
Stanimir Vuk-Pavlović, Bojan Benko, Vesna Svetličić
}

Introduction: Siniša Maričić, the father of Croatian biophysics, passed away on October 31, 2017. On this occasion, three of his students wish to share the memory of their teacher with the readers of the Croatica Chemica Acta.

SV-P: As Dr. Maričić's students from his period in biophysics we claim, perhaps selfishly, that this period left his most significant legacy. His unique bequest to our science is from the shortest period of his activity: his pioneering contribution to the development of biophysics, biophysical education and the quantitative approach to biological problems. He was our teacher in the fullest sense of the terms; he influenced us by his personality. Hence, let us neither list nor analyze Dr. Maričić's numerous contributions to chemical technology in the wake of World War II, his leadership in biophysics after that and his final period in "science about science" ${ }^{[1-4]}$ rather, let us share personal memories about him.

BB: Since early at high school I was interested in science. I believed I would study physics. However, an excellent chemistry teacher taught me much more than the curriculum required. Consequently, I studied chemistry, but remained interested in physics. In the fall of 1972, I worked on my B.Sc. graduation thesis at the Ruđer Bošković Institute in Zagreb. My mentor at the time, Professor Nenad Trinajstić asked me if I would be interested in biophysics. I did not know what biophysics was. Prof. Trinajstić directed me to Dr. Maričić who led the Laboratory of Structural Biophysics in the adjacent building of the University Institute of Physics. I did not know how to prepare for the visit. With some anxiety I looked for Dr. Maričić in his lab. Impressive beard, blue eyes, calm demeanor-as if he sensed my anxiety. It took a few short minutes for anxiety to disappear. We discussed my interests and expectations and only later about what he could offer. We agreed in no time. Today I know that the results of this meeting vastly surpassed all my expectations.

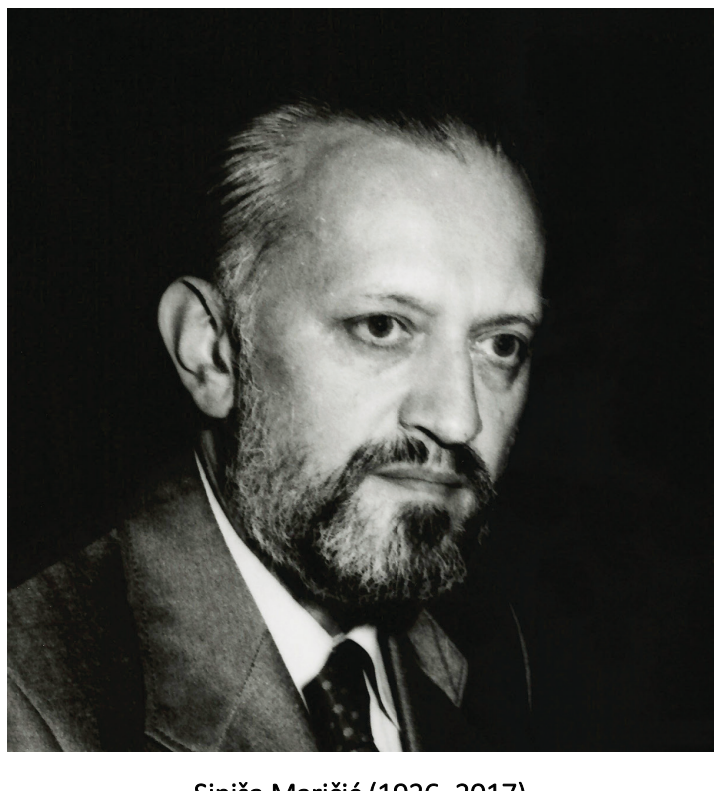

Siniša Maričić (1926-2017)

SV-P: Dr. Maričić was both my M.Sc. and Ph.D. mentor. I worked with him from the fall of 1972 to December 1976, altogether some four years and a quarter. I met him first a few short months following my graduation. I knew Professor Krista Kostial and sought her advice where to go and what to do for my graduate studies: "Maričić does quantitative science. Talk to him!" As I had just graduated from a program where I heard explicitly that "biology is not a quantitative science", I had no doubt what to do.

Dr. Maričić received me at the Institute of Biology that he led at the time. Prof. Kostial prepared me with the information that the future of the Institute hung in balance.

(cc) BY This work is licensed under a Creative Commons Attribution 4.0 International License. 
Talking with Dr. Maričić I realized the program I just graduated from prepared me rather poorly for biophysical research of Maričić's kind, but it was immediately clear that I have to accept the challenge. At the end of conversation Dr. Maričić told me it was possible that "the Institute could sink, and I could sink with it". I replied something like "It is better to sink with the good, than float with the bad." At that moment, our relationship had been established; from time to time, Dr. Maričić would refer to this exchange of ours.

BB: Biophysics was truly young in Croatia at the time and I had the opportunity to work in this best of places. Dr. Maričić gathered young biologists, physicists and chemists, he equipped the first biophysics laboratory in Croatia and obtained funding for several years of studying the structure and function of hemoproteins. He organized the interuniversity graduate program of structural biophysics taught by the best professors and established scientists from Zagreb and Ljubljana. In the Seventies this was the only instruction in biophysics in the former Yugoslavia. A part of this program was delivered through summer schools attended by students and specialists from other disciplines from entire former Yugoslavia and abroad. Instruction level was very high; in addition, it allowed the students to meet some of the world's best scientists at the time. The goal of the program was to link physics, chemistry and biology in resolving biological problems and to provide the students with complementary knowledge they could not obtain from the study of their basic discipline. Later Dr. Greta Pifat, Dr. Maričić's longtime collaborator, transformed the summer school into a series of major international events.

VS: I have never worked with Dr. Maričić, but I did take part in the graduate summer schools of biophysics, for the first time at Ilidža near Sarajevo in 1973. I was deeply immersed in biophysics that he introduced and established in Croatia. Since my own academic beginnings I looked at science through the same eyes as Dr. Maričić. His graduate program allowed me to articulate my own research subject area, membrane transport, the area that ultimately led me to marine biophysics. Enthusiasm, ethics, love of nature-all this somehow touched us, young scientists at the initiation of our research careers.

BB: Instruction at the graduate program in structural biophysics was good, useful and interesting, but the central role was played by research. To students and collaborators Dr. Maričić granted broad freedom and stimulated them to come with their own ideas and initiatives while striving to provide the best possible conditions for research. His laboratory contained the first pulse nuclear magnetic resonance spectrometer in Croatia adapted for relaxation measurements; an optical rotation dispersion/circular dichroism spectrometer; ultraviolet/visible range spectrometer, and basic equipment for isolation and purification of biomacromolecules. Laboratory potential was enhanced by multiple collaborations with the Ruđer Bošković Institute in Zagreb, Jožef Stefan Institute in Ljubljana, Faculty of Agriculture and Food Science in Skopje, Central Institute of Molecular Biology/Max Delbruck Center for Molecular Medicine in Berlin, Institute of Crystallography of the Russian Academy of Science, etc. Such environment stimulated growth of students into productive researchers in the then quite competitive field of structure and function of hemoproteins.

SV-P: Laboratory was placed at the Institute of Physics at Bijenička Street. As students and collaborators used to work very long hours, from time to time it became obvious that Dr. Maričić could not be found in his office on the ground floor. That was the time of his membership and work at the Central Committee of the League of Communists of Croatia that consumed quite a bit of his time. Realizing that we missed his presence and leadership, occasionally he would complain about the time dedicated to this activity. "But, Dr. Maričić, why are you doing it if it tires you so much and wastes so much time and energy?" "You know, Vuk, in fact, nobody does what one does not want to do!" Some time later he withdrew from politics. As much as I can remember, he indicated he had done it as a matter of principle.

Time spent in the lab was very productive. The rather large number of papers published allowed Dr. Maričić to teach the principles that remained with me forever. Among these is that listing the authors of a publication needs to be just, but also generous: "You know, Vuk, in the end it is always clear who is good and who is not." Productivity led to invitations to write reviews of our scientific area: "Stick to the primary production, leave the reviews to others!"

BB: At the end of 1974, the University Institute of Biology folded and the Laboratory for Structural Biophysics and its personnel moved to the University Institute of Immunology in Zagreb. Research continued at the new address for the next three years, it even expanded into the then novel and highly interesting field of cytochrome P-450.

SV-P: Dr. Maričić did not take the demise of the Institute of Biology and the move to the Institute of Immunology lightly. The new environment posed new and unexpected challenges to all members of the group. The challenges were not eased by problems in maintenance and further development of the then rather unique instrumentation. Nonetheless, the effort and high standing of Dr. Maričić in 
Zagreb and at the Jožef Stefan Institute in Ljubljana ascertained the function of the laboratory and timely completion of the manuscripts for publication and theses for academic promotion.

At the return from a postdoctoral stay abroad at the very end of 1977, on the table of my living room I found a long handwritten letter whereby Dr. Maričić informs me that he was leaving the Institute of Immunology. Unfortunately, I have not kept the letter, but I can remember that the letter expressed the concern for my professional future. He wrote about the principled reasons why he had to leave. His departure from the Institute of Immunology terminated our collaboration and, in large part, our contacts at the time. Later we would meet quite regularly again, mostly at the time of his birthday, until a few short years ago when health issues became a burden.

VS: I led the Croatian Biophysical Society from 2002 to 2010. Dr. Maričić's presence in the Society was quiet, but he contributed enthusiasm, strength and seriousness. He was a pillar of dignity for the Society and, by virtue of it, for the standing of biophysics in our scientific community. He followed the direction of progress, main achievements and, occasionally, departures from biophysics. We discussed the establishment of marine biophysics and the establishment of the Ph.D. program in biophysics at the School of Science and Mathematics, University of Split. At the Society meetings he would always sit in the last row, but was first in paying his annual dues.

At the annual meeting of the Society on January 27 , 2017 we elected Dr. Maričić the first honorary member. In support of the proposal, Society president N. Pavin presented Dr. Maričić as the pioneer in establishing biophysics in the former Yugoslavia and as the founder and first president of the Yugoslav Biophysical Society to which the Croatian Biophysical Society is a de facto successor. I supported the proposal by presenting Dr. Maričićs role in the initial steps of biophysics within and without Croatia.
BB: The five splendid years spent with Dr. Maričić in his role of mentor, scientist and human being have profoundly influenced my professional life.

VS: In the end, we shared our years in retirement. In fact, this was the continuation, expansion, and upgrade of the garden of our professional relationship. He supported the engagement in science and concrete social activities removed from politics.

SV-P: One could disagree with Dr. Maričić on some views of life, but one had always to respect him for sincerity and strength of conviction. He was a leader in scientific development. He was honest. He was a decent human being. In his long life, on multiple occasions he had to leave from somewhere, but he left adhering his principles. He left upright to the end.

BB: Bojan Benko, bojan.benko@gmail.com

VS: Vesna Svetličić, svetlicic@irb.hr

SV-P: Stanimir Vuk-Pavlović, vuk@mayo.edu

\section{REFERENCES}

[1] Dr. Maričić's biography, including his comprehensive bibliography, can be reached at borut.com/sinisa_maricic/ (in Croatian).

[2] Contributions to development of biophysics and nuclear magnetic resonance in Croatia are described on the web pages of the Croatian Biophysical Society (www.biofizika.hr/onama/iz-povijesti-drustva) and Faculty of Science, University of Zagreb (www.pmf.unizg.hr/ phy/NMR/nmr_tehnika/nmr_u_hrvatskoj; in Croatian).

[3] Dr. Maričić testifies about his life in the video available at: www.osobnasjecanja.hr/video-arhiva/sinisa-maricic (in Croatian).

[4] Editor's Note: From 1980 to 1985 Dr. Maričić served as Editor-in-Chief of this journal. For his service, the Croatian Chemical Society owes him a debt of enduring gratitude. 